оналізму, компетентності та комунікабельності, що є запорукою успішної фахової діяльності.

\title{
Література:
}

1. Кудря І.П., Шевченко Т.І., Третяк Н.Г., Шапошник О.А. Оптимізація самостійної роботи студентів у світлі інноваційних освітніх технологій при вивченні внутрішньої медицини. Східноукраӥнський медичний журнал. 2020. Т. 8. № 2. С. 195-203.

2. Романцов М.Г., Сологуб Т.В. Педагогические технологии в медицине: учебное пособие. М.: ГЭОТАР-Медиа, 2007. 112 с.

3. Свистунов А.А. Протопопов А.А., Ребров А.П., Пономарева Е.Ю., Волошинова Е.В. Организация учебного процесса в интернатуре по внутренним болезням. Саратовский научномедициинский журнал. 2010. № 1. С. 206-208.

4. Воробйов Є.О., Шевченко Т.I., Сорокіна С.І., Кудря I.П., Шапошник О.А. Шляхи оптимізації проведення лікарської виробничої практики 3 внутрішньої медицини у студентів 4 курсу медичних вузів в умовах Болонського процесу. Медична освіта. 2011. № 3. С. 55-58.

DOI https://doi.org/10.30525/978-9934-588-81-5-2.16

\section{КЛЕТОЧНЫЙ СОСТАВ ПЕРИФЕРИИ ОЧАГА ВОСПАЛЕНИЯ ПРИ ХРОНИЧЕСКОМ ВОСПАЛЕНИИ НА ФОНЕ ВВЕДЕНИЯ ГЛЮКОЗАМИНИЛМУРАМИЛДИПЕПТИДА}

\author{
Шевченко А. Н. \\ доктор медицинских наук, профессор,
} профессор кафедры патологической физиологии имени Д. Е. Альперна

Харьковский национальный медицинский университет

\section{Бибиченко В. А.}

кандидат медицинских наук, ассистент кафедры патологической физиологии имени Д. Е. Альперна Харьковский национальный медицинский университет

$$
\text { 2. Харьков, Украина }
$$

Лечение воспалительных процессов глюкокортикоидными гормонами, другими иммунодепрессантами создает реальную угрозу для перехода воспаления в хроническую форму. 
Хроническое воспаление является проявлением возникшего дефекта в системе защиты и приспособления организма к меняющимся условиям существования [1, с. 39-44].

В связи с необходимостью обоснования стратегии профилактики и лечения хронического воспаления представляет интерес его общие закономерности, а также ситуация в очаге и прежде всего клеточные взаимодействия, детерминирующие развитие и исходы воспалительного процесса [2, с. $33 ; 3$, с. $101 ; 4$, с. 470-477].

Целью исследования является изменение клеточного состава периферии очага воспаления при хроническом воспалении на фоне введения глюкозаминилмурамилдипептида.

Материалы и методы. Опыты проведены на 132 крысах-самцах линии Вистар массой тела 180-200г. Хроническое воспаление вызывали внутримышечным введением в область бедра 10 мг $\lambda$-карагинена (Sigma, США) в 1 мл изотонического раствора хлорида натрия [5, c. 24-28; 6, c. 249-253].

Глюкозаминилмурамилдипептид вводили под кожу спины крысам в дозе 0,1 мг в 0,5 мл изотонического раствора натрия хлорида ежедневно на протяжении всего эксперимента.

Контролем для естественного течения воспаления были интактные крысы, для воспаления на фоне применения глюкозаминилмурамилдипептида - крысы, которым вводили препарат без последующего вызывания воспаления.

Животных забивали декапитацией под наркозом на 6-й час, 1-е, 2-е, 3-и, 5-е, 7-е, 10-е, 14-е, 21-е и 28-е сутки воспаления.

Результаты исследования.

Число нейтрофилов увеличивается значительно на протяжении 3-х суток, и в последующие сроки постепенно снижается, к окончанию эксперимента приближается к контролю.

Количество эозинофилов значительно повышается на1-е и 2-е сутки, достигая максимальных значений, и также с 6-го часа до 14-х суток сохраняется достоверное повышение количества эозинофилов в сравнении с контролем.

Содержание моноцитов увеличено во все сроки исследования с пиком на 7-е - 10-е сутки.

Количество лимфоцитов повышено во все сроки исследования. Максимальное повышение наблюдается на 7-е и 10-е сутки.

Количество плазмоцитов значительно увеличено во все сроки исследования. При этом отмечаются две фазы повышения их числа: на 6-й час - 5-е сутки, с пиком на 5-е сутки (максимум), и на 7-е 28 -е сутки с пиком на 10 -е сутки. 
Содержание макрофагов увеличено во все сроки исследования, с постоянным нарастанием с 1 -х суток до 28 -х суток, когда количество макрофагов является максимальным.

Количество тканевых базофилов повышено во все сроки исследования с максимумом на 14-е сутки.

Фибробласты обнаруживаются со 2-х суток, и их количество постепенно увеличивается с пиком на 28 -е сутки.

Таким образом, на периферии очага воспаления по сравнению с центром меньше выражена инфильтрация нейтрофилами и эозинофилами, но значительно больше - моноцитами и лимфоцитами. Плазматизация лимфоцитов выражена больше на периферии очага воспаления. Реакция клеток соединительной ткани также больше выражена на периферии очага воспаления в связи с тем, что репаративные явления начинаются с периферии очага и идут по направлению к центру за счет соединительнотканных элементов [7, с. 415-430].

Содержание нейтрофилов на периферии очага воспаления при вторично хроническом воспалении на фоне введения глюкозаминилмурамилдипептида свидетельствует о том, что наблюдается выраженная нейтрофильная инфильтрация в течении первых 10-ти суток с максимумом на 1-е и 3-и сутки. С 5-х суток до 10 -х суток количество нейтрофилов существенно уменьшается в сравнении с 3-ми сутками, но продолжает достоверно превышать контроль соответственно в 12,87 раза; 8,78 раза; 8,07 раза. С 14 -х до 21 -х суток наблюдается тенденция повышения количества нейтрофилов соответственно в 4,63 раза, 3,09 раза. К 28-м суткам наблюдается снижение количества нейтрофилов в сравнении с контролем в 1,21 раза.

Количество моноцитов повышено во все сроки исследования, и его увеличение является фазным. Первая фаза наблюдается с 6-го часа по 5-е сутки с пиком на 3-и сутки, вторая фаза - на 7-е - 28-е сутки с пиком на 10-е сутки.

По сравнению с естественным течением воспаления содержание моноцитов имеет тенденцию к повышению со 2-х суток до 28-х суток.

Содержание лимфоцитов повышено во все сроки исследования, особенно со 2-х суток до 28-х суток с пиком на 7-е сутки. По сравнению с естественным течением воспаления количество лимфоцитов характеризуется тенденцией к увеличению на 6-й час; 2-е сутки, 5-е сутки - 28-е сутки, а тенденцией к снижению на 1-е сутки и 3 -и сутки.

Количество плазмоцитов повышено во все сроки исследования. При этом наблюдается две фазы увеличения их содержания с пиком на 5-е и 10 -е сутки. 
По сравнению с естественным течением воспаления число макрофагов имеет тенденцию к снижению на 6-й час и 1-е сутки и тенденцию к повышению со 2-х суток до окончания эксперимента.

Содержание тканевых базофилов повышено практически во все сроки исследования с максимумом на 14-е сутки.

По сравнению с естественным течением воспаления количество тканевых базофилов появляется тенденция к снижению на 6-й час; 1-е сутки; 14-е, 21-е и 28-е сутки, а тенденцией к повышению начиная со 2-х суток по 10-е сутки.

Фибробласты в контроле, а также на 6-й час, 1-е сутки воспаления не обнаруживаются. На 2-е сутки они появляются в небольшом количестве $(0,29 \pm 0,41$ экз. на принятую единицу площади ткани). На 5-е сутки их содержание существенно увеличивается по сравнению с предыдущими сроками. В дальнейшем оно постоянно нарастает по 28 -е сутки, когда является максимальным (14,13 $\pm 1,75$ экз.).

Соответственно, фибробласты появляются на 2-е сутки, и их количество прогрессивно увеличивается во все сроки исследования.

По сравнению с естественным течением воспаления количество фибробластов имеет тенденцию к увеличению во все сроки исследования.

Таким образом, использование глюкозаминилмурамилдипептида влияет на содержание клеточных элементов, характерных для воспалительной реакции, а изменения клеточного состава очага карагиненового воспаления на его периферии идентичны таковым в центре, однако менее выражены.

\section{Литература:}

1. Пауков В. С. Иммунное гранулематозное воспаление как приспособи-тельная реакция организма. Архив патологии. 2014. № 4. T. 76. C. 39-44.

2. Клименко Н. А. Гематологические механизмы хронизации воспаления Харьков: ХНМУ. 2010. 88 с.

3. Koyasu S. Role of innate lymphocytes in infection and inflammation. Front Immunol. 2012. Vol. 3. P. 101.

4. Monocyte trafficking in acute and chronic inflammation. Trends Immunol. 2011. Vol. 32. № 10. P. 470-477.

5. Клименко Н. А. Обоснование модели хронизирующегося (вторично хронического) воспаления. Експерим. і клініч. медицина. 2007. № 2. C. 24-28.

6. Клименко Н. А. Роль лейкоцитов в реакции тучных клеток очага воспаления. Бюл. эксперим. биологии и медицины. 1993. № 9. C. $249-253$. 
7. Shevchenko A. N. Dynamics of changes of cellular composition of the centre of focus of inflammation in secondary chronic inflammation during treatment with glyukozaminilmuramildipeptid. Journal of Education, Health and Sport. 2017. Vol. 7. № 2. P. 415-430.

DOI https://doi.org/10.30525/978-9934-588-81-5-2.17

\title{
ДОЦІЛЬНІСТЬ ВРАХУВАННЯ ВІКОВОЇ ДИНАМІКИ ІНТЕГРАТИВНИХ ПАРАМЕТРІВ ЩУРІВ ПРИ ВІДТВОРЕННІ МЕТАБОЛІЧНОГО СИНДРОМУ В ЕКСПЕРИМЕНТІ
}

\author{
Шутова Н. А. \\ кандидат медичних наук, \\ доцент кафедри патологічної фізіології імені Д. О. Альперна \\ Харківський національний медичний університет \\ м. Харків, Украӥна
}

Вступ. В сучасних умовах домінуючу роль в розвитку метаболічного синдрому (МС) відіграють екзогенні чинники, особливо надмірне харчування, що призводить до розвитку ожиріння [1] і підвищує частоту зрушень вуглеводного і ліпідного обмінів [2]. Саме підвищення індексу маси тіла (IMT) вважають головним пусковим механізмом розвитку МС, а медичні терміни «ожиріння» та «надмірна вага» $\epsilon$ ключовими для поняття IMТ. Так, встановлено лінійну залежність розвитку цукрового діабету від приросту маси тіла $[3,4,5]$, де резистентність до інсуліну розглядається, як основна причина серцевосудинних захворювань [6], асоційованих із дисліпідемією, гіпертонічною хворобою та атеросклерозом [7, 8]. Відомо, що загальна жирова маса, IMT, окружність талії, внутрішньочеревний жир і загальний черевний жир значно пов'язані з резистентністю до інсуліну [9], що є руйнівною силою метаболічної дисфункції. Таким чином, IMT, вважається кращим предиктором для інсулінорезистентності з різних причин, в тому числі і економічних.

Треба зазначити, що дані про динаміку маси тіла тварин в експерименті, як одного із інтегративних показників організму, на тлі експериментального моделювання ожиріння у вітчизняній літературі практично відсутні, а в закордонній - не повні і суперечливі [10]. Складність ситуації також полягає в тому, що на цю недугу де далі страждають діти і підлітки. За останні двадцять років кількість огряд- 